\title{
Da caatinga e dos catingueiros: ethé paratópicos no discurso literomusical de Elomar Figueira Mello
}

\author{
On the caatinga-biome and the native people: the paratopic ethe in the \\ braziliam litero-musical discourse of Elomar Figueira Mello \\ Lia Raquel Vieira de Andrade ${ }^{1}$ \\ Juliana Geórgia Gonçalves Araújo² \\ 1 Universidade da Integração Internacional da Lusofonia Afro-Brasileira, Redenção, Ceará, Brasil. \\ 2 Universidade Federal de São Carlos, São Carlos, São Paulo, Brasil.
}

\begin{abstract}
Resumo: Propomos apresentar um breve estudo do discurso de Elomar Figueira Mello compositor, intérprete e violonista, que tem como fonte de inspiração o espaço, a cultura e o povo do sertão - através da aplicação do conceito de paratopia na constituição dos ethé nas cenografias dos textos. Para tanto, apresentaremos a análise do plano textual de duas canções intituladas "O violeiro" e "Campo branco", em que podem ser observados elementos que configuram o caráter paratópico da obra literomusical de Elomar. O objetivo principal do artigo consiste em verificar como a paratopia, observada no investimento ético do plano verbal das canções, é um dos fatores constitutivos na demarcação do posicionamento do compositor no campo literomusical brasileiro.
\end{abstract}

Palavras-chave: ethos; paratopia; sertão.

\begin{abstract}
The litero-musical discourse in the work of the composer, guitarist, poet and singer Elomar Figueira Mello is investigated in the framework of the theory of the Discourse Analysis, in which we consider the aspects related to the concepts of paratopia and ethos. The work of Figueira Mello is funded on the colonial Brazil of the 17th century and, in particular, he brings back the language, the music and the environment of that time, with the objective of value the Brazilian culture. We analyze two of the most relevant pieces of the composer, namely "O violeiro" and "Campo Branco", in which we have found strong paratopic marks, which characterizes this positioning in the Brazilian litero-musical scenario.
\end{abstract}

Keywords: ethos; paratopia; sertão.

\section{Introdução}

Neste artigo, apresentamos a maneira como o discurso literomusical do compositor Elomar Figueira Mello se constitui paratopicamente, através da construção de ethé paratópicos na cenografia de suas composições a fim de garantir a demarcação de seu posicionamento no campo da música brasileira. Para esse propósito, analisamos os textos das canções "O violeiro" e "Campo branco" com a observação dos embreantes paratópicos na caracterização dos ethé e no código de linguagem apresentados no plano verbal das canções.

A paratopia foi abordada por Maingueneau (2001, 2006) a partir da sua aplicação ao campo discursivo da literatura, em que é entendida como a condição do autor no processo de elaboração e enunciação das obras. Essa condição, por sua vez, é refletida na própria enunciação, através de elementos denominados "embreantes paratópicos", que fazem uma espécie de elo entre o universo representado pela obra e a condição paratópica do autor. Já a questão do ethos é abordada em diversos trabalhos do pesquisador (MAINGUENEAU, 2001, 2006, 2008b, 2013), nos quais propõe uma definição de ethos como a imagem construída do locutor pelo destinatário no ato da enunciação.

Assim, a partir dos estudos de Maingueneau (2001, 2006, 2008b, 2013) acerca da paratopia e do ethos no campo literário, retomamos tais conceitos para a análise 
da obra de Elomar Figueira Mello no campo literomusical, levando em consideração ainda a perspectiva de Costa (2012), que afirma que o discurso literomusical brasileiro admite pretensões constituintes, dado que, em nosso contexto histórico e social, a música popular influencia a constituição de uma identidade nacional.

A opção pelo estudo da obra de Elomar - como é conhecido no meio artístico - surgiu, em princípio, da constatação de que esse compositor apresenta qualidades expressivas no campo discursivo da música brasileira, visto que é autor de uma obra que contempla aspectos eruditos e populares, ao resgatar o passado históricocultural do povo sertanejo, fazendo referências a elementos da herança galego-portuguesa medieval, conservadas no cancioneiro popular nordestino e na literatura de cordel.

Elomar é caracterizado por manter um posicionamento contrário a tudo que representa a modernidade, entendida como algo impuro e danoso. O modo de vida adotado nos grandes centros urbanos, assim como a imposição de certos valores difundidos pela mídia através dos meios de comunicação nos rincões do país, têm como consequência, na visão do compositor, a perda da ingenuidade e da pureza dos habitantes da zona em que está situado o sertão, sobretudo daqueles mais jovens. Desse modo, a temática elomariana tem como referência o povo, o espaço e a cultura de um sertão cronologicamente remoto. No plano verbal, o compositor utiliza, na maioria das canções, um código de linguagem que faz referência à variedade linguística regional com marcas do português arcaico. Já no plano musical, há uma inter-relação de referências da música erudita, da música ibérica e de gêneros musicais típicos da cultura nordestina.

Costa (2012) considera Elomar o maior representante da "canção catingueira", nomenclatura referente às produções musicais do agrupamento discursivo dos "catingueiros", termo que remete à caatinga, vegetação típica do interior nordestino. Esse termo é utilizado por Costa (2012) para designar o grupo de compositores e intérpretes que cantam temas voltados para essa região, dentre os quais Elomar destaca-se por servir de referência para o posicionamento de vários compositores e intérpretes, como Xangai, Vital Farias, Dércio Marques, Carlos Pita, Fábio Paes, Geraldo Azevedo, Roze, entre outros.

Intencionamos, neste artigo, verificar como a paratopia, manifestada através da embreagem paratópica, na cenografia (que abrange a construção de ethé) no plano verbal das canções, garante a demarcação do posicionamento do compositor no discurso literomusical brasileiro.

A análise pretenderá verificar o significado das produções de Elomar no quadro da música brasileira assim como a situação de enunciação dessas produções.
Concluída a parte analítica, atribuiremos significados mais amplos aos resultados, identificando como a paratopia legitima o posicionamento discursivo do compositor, caracterizado pelo enaltecimento dos valores sertanejos, considerados puros em oposição aos valores superficiais e impuros da urbe.

Antes da análise, apresentamos uma breve abordagem do conceito de paratopia discursiva e de ethos discursivo; enfocamos, ainda, a questão da paratopia no discurso literomusical brasileiro a partir da pesquisa de Costa (2012). Em seguida, apresentamos as análises das canções "O violeiro" e "Campo branco" e, finalmente, apresentamos algumas considerações acerca da constituição paratópica da obra do compositor e do seu posicionamento no campo literomusical do Brasil.

\section{As noções de paratopia e de ethos}

\subsection{Paratopia}

De uma forma simplificada, a paratopia é entendida como "a relação paradoxal de inclusão/exclusão em um espaço social que implica o estatuto de locutor de um texto que decorre dos discursos constituintes" (CHARAUDEAU; MAINGUENEAU, 2008, p.368), sendo os discursos constituintes aqueles que se estabelecem como fundadores dos demais discursos numa sociedade, em determinada época e lugar:

Eles [discursos constituintes] operam a mesma função na produção simbólica de uma sociedade, uma função que poderíamos chamar de archeion. [...] O archeion associa assim intimamente o trabalho de fundação no e pelo discurso, a determinação de um lugar associado a um corpo de enunciadores consagrados e uma gestão da memória. (CHARAUDEAU; MAINGUENEAU, 2008, p. 37-38, grifos dos autores)

São considerados constituintes os discursos religioso, científico, filosófico e literário. Contudo, há discursos que têm estatutos problemáticos e que devem ser vistos com um olhar mais apurado, como é o caso de discursos como o político, o musical, dentre outros, que muitas vezes buscam apoio na ciência, na religião, na filosofia ou na literatura para se fundamentar.

A paratopia é observada na representação de determinada tensão que ocorre na relação entre enunciador (autor), campo discursivo e sociedade. Assim, a paratopia se dá concomitantemente no plano da instituição dos discursos constituintes e no plano da criação das obras, caracterizando a circunstância que determina os discursos e a condição de seus autores. $\mathrm{O}$ enunciador de discurso constituinte cria modos peculiares de produção, geralmente vivenciando um afastamento da sociedade, num ritual de autoexílio, que gera tensão entre a sua 
condição de autor e a sua condição de indivíduo social. Um escritor de texto literário, por exemplo, enuncia a partir do paradoxo em que vive: não encontra um verdadeiro lugar nem na sociedade (pois precisa manter um afastamento dela para poder criar), nem no campo literário (porque deve estar ancorado à sociedade e suas instituições). É exclusivamente do embate entre espaço discursivo e sociedade que emerge a enunciação.

A condição paratópica do autor pode se refletir na enunciação de diversas maneiras. Maingueneau (2006) caracteriza a paratopia do autor em tipos: a "paratopia de identidade", que "apresenta todas as figuras da dissidência e da marginalidade, literais ou metafóricas: meu grupo não é meu grupo" (MAINGUENEAU, 2006, p.110); a "paratopia espacial", que abrange a figura do exilado: "meu lugar não é meu lugar ou onde estou nunca é meu lugar" (MAINGUENEAU, 2006, p. 110); a "paratopia temporal", fundada no anacronismo "meu tempo não é meu tempo. Vive-se aí na modalidade do arcaísmo ou da antecipação: sobrevivente de uma época passada ou cidadão prematuro de um mundo por vir" (MAINGUENEAU, 2006, p. 110); e a "paratopia linguística", ligada ao investimento linguístico de uma obra. É importante ressaltar que esses tipos de paratopia se mesclam, de modo que a especificação de cada um deles foi pensada para uma maior clareza na compreensão do processo de criação das obras.

$\mathrm{Na}$ aplicação da noção de paratopia ao discurso literário, Maingueneau $(2001,2006)$ indica elementos textuais que representam a condição paratópica do autor. Tais elementos são denominados de embreantes e sua inserção nos textos se dá pela embreagem paratópica. Os embreantes paratópicos estão condicionados aos seguintes eixos semânticos: o dos espaços paratópicos, que são "lugares subtraídos em certa medida das injunções da sociedade comum" (MAINGUENEAU, 2001, p. 174); das personagens paratópicas, representadas por grupos ou indivíduos; dos tipos de paratopia, que podem pertencer a dois eixos maiores (social e geográfico); da condição limite do elemento paratópico, que varia entre condição máxima e mínima de paratopia; e por fim, da relação entre elementos paratópicos e sociedade estabelecida, que podem ser de marginalidade, de antagonismo e de alteridade.

Nessa perspectiva, a embreagem paratópica ocorre nos investimentos discursivos da cenografia, do ethos, da língua etc., como um elo entre o mundo "real" e o universo representado na enunciação.

\subsection{Ethos}

Maingueneau (2006, p. 269) considera algumas teses de base acerca da noção de ethos, a partir da Retórica de
Aristóteles - na qual há a apresentação de uma techne que tem por objetivo observar o que é persuasivo para determinados tipos de indivíduos -, são elas: o ethos é uma noção discursiva, pois é construído a partir do discurso; o ethos está associado a um processo interativo de influência entre enunciador e destinatário; o ethos é um conceito invariavelmente híbrido - sociodiscursivo - que não pode ser apreendido no exterior de uma situação de comunicação precisa, que, por sua vez, faz parte de uma conjuntura sócio-histórica.

O ethos, portanto, não está relacionado a um conhecimento extradiscursivo sobre o enunciador, mas está integrado na própria enunciação. O destinatário deve construir uma imagem (uma representação) do enunciador, a partir dos indícios que este apresenta na enunciação. O ethos possibilita ainda uma (não) adesão dos sujeitos ouvintes ao ponto de vista defendido por um discurso.

Maingueneau (2001, 2006, 2008b) traz à discussão algumas dificuldades ligadas à noção de ethos, que, apesar de estar associada à enunciação, há também o fato de que o público constrói previamente representações do ethos do enunciador. A partir dessa constatação, é necessário que se estabeleça uma distinção entre ethos discursivo e ethos pré-discursivo (ou prévio), na qual apenas o primeiro está relacionado à definição aristotélica. Todavia, a distinção entre as duas designações deve levar em conta a diversidade de tipos, de gêneros do discurso e de posicionamentos, pois, "mesmo que o destinatário nada saiba antes do ethos do locutor, o simples fato de um texto estar ligado a um dado gênero do discurso ou a um certo posicionamento ideológico induz expectativas no tocante ao ethos" (MAINGUENEAU, 2006, p. 269).

Dessa forma, o ethos discursivo é o resultado da ação recíproca do ethos pré-discursivo e do ethos discursivo (mostrado) e ainda do ethos dito, identificado nos "fragmentos do texto em que o enunciador evoca sua própria enunciação, diretamente ("é um amigo que vos fala') ou indiretamente, por exemplo, por meio de metáforas ou alusões de outras cenas de fala" (MAINGUENEAU, 2006, p. 270). É por meio da interação entre essas instâncias - cuja força varia de acordo com os gêneros de discurso - que o ethos efetivo é construído pelo destinatário.

À figura do enunciador é associado um caráter, que "corresponde a um conjunto de características psicológicas" (MAINGUENEAU, 2006, p. 272) e uma corporalidade, "uma compleição física e a uma maneira de se vestir" (MAINGUENEAU, 2006, p. 272). Conforme Mainguenau (2006, p. 272), a apropriação do ethos pelo receptor é denominada de "incorporação" e ocorre em três etapas: 1) o fiador (enunciador) expõe uma corporalidade através da enunciação; 2) o destinatário incorpora essa 
corporalidade; 3 ) ocorre a constituição de um corpo, que representa o grupo imaginário dos que se unem ao mesmo discurso. É por meio da incorporação que o destinatário identifica o mundo ético, sugerido pelo enunciador, que compreende certas situações estereotípicas ligadas a comportamentos de determinadas épocas e lugares, em que se enquadram variados tipos de ethé.

Maingueneau (2006, p. 288) observa que a incorporação convocada pelo ethos parte da corporalidade do texto, que, por sua vez, está sujeito às coerções do gênero, no processo que descreve como incorporação textual. Dessa forma, o ethos é passível de incorporação pelo destinatário através da cenografia contida em uma materialidade textual subordinada a um gênero; todo esse procedimento, por sua vez, está vinculado ao posicionamento discursivo do enunciador.

Dessa forma, em nossas análises lançamos mão da definição de ethos como uma instância enunciativa, que participa da cenografia do plano textual das canções. É a partir da composição de determinados ethé que a paratopia, em suas mais variadas formas, pode se manifestar a partir da construção de uma imagem pelo destinatário/ouvinte; tal imagem é construída a partir de um conhecimento prévio, que aciona um mundo ético. No caso das canções de Elomar, a referência do sertão deslocalizado temporalmente, como um mundo ético reproduzido na enunciação, representa a demarcação de um posicionamento discursivo também pautado em uma paratopia. Para um melhor esclarecimento acerca da paratopia no campo literomusical brasileiro, apresentamos, a seguir, um breve apanhado do estudo de Costa (2012).

\section{Paratopia e o campo literomusical}

Costa (2012) faz uma análise da canção popular brasileira enquanto discurso, utilizando os conceitos teóricos da Análise do Discurso de linha francesa. O pesquisador faz uma descrição da música popular brasileira partindo das características dos movimentos e vertentes cujas práticas discursivas ultrapassam os limites da produção efetiva das canções para atuar também nos discursos que elas produzem ou virão a produzir.

O campo literomusical é um espaço de produção e circulação de determinados gêneros de discurso integrados a comunidades de especialistas. Existem práticas discursivas que determinam uma partição entre a gravação e execução das canções (discursos primeiros) e a produção de textos acerca dessas canções (discursos segundos), que englobam comentários, análises, estudos etc. Tal como ocorre com os enunciadores de discurso literário, a consciência artística dos enunciadores de discurso literomusical é refletida pela forma como se posicionam no campo discursivo e na conjuntura social em que estão inseridos. Eles são tomados pela necessidade de intervir na realidade e, para isso, adotam práticas como a composição, as apresentações, as produções e gravações das canções em álbuns etc.

Portanto, tal como o discurso literário, o discurso literomusical no Brasil tem uma instituição paratópica, de localidade paradoxal (pertencimento e afastamento) do contexto social, uma vez que a prática discursiva de composição de obras literomusicais se assemelha em muitos pontos à prática de produção de textos literários. No plano da representação, a paratopia pode ser observada pela embreagem paratópica, uma vez que, assim como o autor de textos literários, o compositor de canções traça seu percurso numa paratopia criadora, trazendo para a enunciação os ritos de criação (processos criativos) da obra.

\section{Metodologia}

Partindo da hipótese de Elomar destacar-se no campo literomusical brasileiro pelo posicionamento que aborda a temática catingueira, constituindo seu discurso como paratópico nesse campo, interessa-nos investigar como a paratopia é evidenciada no plano verbal das cações e até que ponto o posicionamento discursivo do compositor se legitima através dessa paratopia.

Selecionamos para análise as canções "O violeiro" e "Campo branco", que foram gravadas, respectivamente, nos álbuns fonográficos Das barrancas do rio Gavião (1972) e Na quadrada das águas perdidas (1978). Justificamos a seleção desses dois álbuns pelo fato de Das barrancas do Rio Gavião (1972) ser um trabalho icônico porque "já contém as linhas básicas do posicionamento [catingueiro]" (COSTA, 2012, p. 186) e Na quadrada das águas perdidas (1978) ter especial relevo, pois "deu uma chave de interpretação para os ouvintes" (CUNHA, 2008, p. 34) através do comentário e glossário dos textos das canções, elaborados pelo historiador Ernani Maurílio Figueiredo, apresentados no encarte do álbum.

Restringimos a nossa análise às duas canções selecionadas por estarem dentre as mais executadas dos álbuns supracitados, seja pelo próprio compositor ou por outros compositores e/ou intérpretes (ocorrência de regravações em trabalhos e/ou execuções da canção nas apresentações), assim como pela referência a tais canções na comunidade discursiva (citações em trabalhos acadêmicos, artigos, resenhas, críticas, entrevistas, comentários etc., execução das canções por orquestras, grupos musicais, corais etc.).

Utilizamos na análise as transcrições dos textos das canções que constam no caderno "Notas e Letras", da coletânea Elomar: cancioneiro (2008), revisados e 
fixados por Guerreiro (2008a), por constituir "cuidadosa correção da linguagem e do dialeto catingueiro, a fim de produzir um material o mais completo e atual possível" (GUERREIRO, 2008a, p. 28).

Assim, verificamos a embreagem paratópica no plano textual das canções selecionadas através da caracterização de ethé paratópicos. Utilizamos a descrição dos tipos de paratopia propostos por Maingueneau (2006) para identificar e descrever os embreantes que representam a paratopia no discurso de Elomar, como podemos observar na seção a seguir.

\section{Ethé paratópicos: os catingueiros de outrora}

O posicionamento catingueiro investe em um ethos caracterizado pela figura do homem rústico, que não incorpora os valores da urbe, mesmo que nela viva ou já tenha vivido. O catingueiro "Prefere recusar os pretensos valores que esse mundo [das grandes cidades] oferece e continuar cultivando os seus mesmo que apenas no âmbito de sua música" (COSTA, 2012, p. 199). Dessa forma, esse posicionamento reflete uma visão maniqueísta, em que o campo (o sertão) representa o que ainda há de puro no mundo ao passo que a urbe representa a corrupção dessa pureza.

Esse ethos rústico, representativo da resistência do posicionamento catingueiro frente à configuração do modo de vida nas grandes cidades, perpassa toda a obra de Elomar e caracteriza o traço comum dos ethé apresentados nas cenografias criadas pelo compositor em seus textos literomusicais. Observamos que o investimento ético, na obra de Elomar, tem forte relação com a paratopia do compositor. Tal relação é apreendida, na enunciação, através da embreagem paratópica (MAINGUENEAU, 2001, 2006), através da constituição de determinados ethé que são elementos (embreantes) paratópicos no plano verbal das canções.

Assim, os indivíduos que habitam o sertão elomariano são caracterizados pela conservação de qualidades como inocência, bravura, honestidade, religiosidade, estoicidade e resistência, qualidades estas que remetem ao período medieval, escolhido pelo posicionamento como a era que melhor praticou e preservou os princípios religiosos, filosóficos e morais da Antiguidade.

Um dos ethé mais atuantes nas cenografias dos textos literomusicais de Elomar é o ethos do errante, que indica duas formas de paratopia: a espacial, caracterizada pela deslocalização e a social, representada pela marginalização. Esse ethos é representado principalmente pela figura do violeiro, que pode ser um cantador ou um menestrel. O violeiro é um embreante paratópico que representa a deslocalização do compositor em relação ao próprio campo discursivo, uma vez que "o autor é alguém que perdeu seu lugar e deve, pelo desdobramento de sua obra, definir um outro, construir um território paradoxal através de sua própria errância" (MAINGUENEAU, 2006, p.131). Juntamente com a característica errante, há uma espécie de boêmia em alguns valores da vida de violeiro, como a liberdade, o fazer artístico sem pretensões lucrativas e o amor verdadeiro.

Nas composições de Elomar, o violeiro é caracterizado a partir do universo da cantoria nordestina. Nesse sentido, o violeiro é o artista popular que, antigamente, participava das cantorias de viola. Atua ainda em uma cenografia que representa o sertão idealizado, denominado pelo compositor de "Sertão Profundo" e, nessa cenografia, o violeiro é uma espécie de menestrel, que canta seus versos à maneira do trovador medieval.

$\mathrm{Na}$ cenografia da canção "O violeiro", há a configuração de um ethos boêmio e errante na apresentação do enunciador, o próprio violeiro, que descreve as suas andanças e peripécias, consequências da profissão de cantador de viola. Essa constituição ética revela uma paratopia sócio espacial: o violeiro, pelo modo de vida que apresenta, pautado na liberdade e no desapego material, é confundido com um vagabundo, como ocorre com os boêmios. Por esse motivo, é posto em uma posição de marginalidade na sociedade, não encontrando um lugar definitivo para si.

O violeiro é um cantador andarilho, que se apresenta em cantorias, entoando várias modalidades de trovas, nas quais são abordados os mais diversos temas, como os acontecimentos da comunidade, os amores e as suas próprias experiências de vida, como se pode verificar no texto da canção:

Vô cantá no cantori primêro / As coisa lá da mĩa mudernage / Qui mi fizero errante e violêro / Eu falo sero e num é vadiage / E pra você qui agora está me ovino / Juro inté pelo Santo Minino / Virge Maria qui ôve o qui eu digo / Se fô mintira me manda o castigo / Apois pra o cantadô e violêro / Só há treis coisa nesse mundo vão / Amô, furria, viola, nunca dinhêro / Viola, furria, amô, dinhêro não / Cantadô de trovas e martelo / De gabinete, ligêra e moirão / Ai cantadô já curri o mundo intêro / Já inté cantei nas porta de um castelo / De um rei qui se chamava de João / Pode acreditá meu companhêro / Dispois de tê cantado o dia intêro / O rei me disse fica eu disse não / Apois pra o cantadô e violêro / Só há treis coisa nesse mundo vão / Amô, furria, viola, nunca dinhêro / Viola, furria, amô, dinhêro não / Si eu tivesse di vive obrigado / Um dia iantes desse dia eu morro / Deus fez os home e os bicho tudo fôrro / Já vi iscrito no Livro Sagrado / Qui a vida nessa terra é u'a passage / E cada um leva um fardo pesado / É um insinament' qui derna a mudernage / Eu trago bem dent' do coração guardado / 
Apois pra o cantadô e violêro / Só há treis coisa nesse mundo vão / Amô, furria, viola, nunca dinhêro / Viola, furria, amô, dinhêro não / Tive muita dô de não tê nada / Pensano qui esse mundo é tudo tê / Mais só dispois de pená pela istrada / Beleza na pobreza é qui vim vê / Vim vê na procissão o lôvado seja / O malassombro das casa abandonada / Coro de ceg' nas porta das igreja / E o ermo da solidão das istrada / Apois pra o cantadô e violêro / Só há treis coisa nesse mundo vão / Amô, furria, viola, nunca dinhêro / Viola, furria, amô, dinhêro não / Pispisno tudo do começo / Eu vô mostrá como faz uma pachola / Qui inforca o pescoço da viola / Rivira toda a moda pelo avesso / E sem arrepará se é noite ou dia / Vai longe cantá o bem da furria / Sem um tustão na cuia o cantadô / Canta inté morrê o bem do amô / Apois pra o cantadô e violêro / Só há treis coisa nesse mundo vão / Amô, furria, viola, nunca dinhêro / Viola, furria, amô, dinhêro não (MELLO, 1972).

$\mathrm{Na}$ cenografia da canção, o enunciador, no ato de uma cantoria, apresenta seu "manifesto", que tem como preceito maior a proclamação da liberdade e do amor como regras de vida.

$\mathrm{O}$ enunciador narra diversas situações vividas por ele em suas andanças ao longo dos anos. A embreagem paratópica se dá na cenografia pela construção do ethos errante e boêmio ("Ai cantadô já curri o mundo intêro"), ("E sem arrepará se é noite ou dia / Vai longe cantá o bem da furria"). Há a narração, em forma de cantoria, da vida e dos valores legitimados pelo violeiro ("Apois pra o cantadô e violêro / Só há treis coisa nesse mundo vão / Amô, furria, viola, nunca dinhêro / Viola, furria, amô, dinhêro não"), valores imateriais, como o amor e a liberdade ("furria").

A errância está relacionada, dessa forma, à liberdade, garantida pelo próprio modo de vida do violeiro, que é o senhor de sua liberdade. A arte, representada no refrão da canção pela viola, garante a liberdade que é muitas vezes privada pelo apego aos bens materiais.

Assim, o violeiro defende os valores espirituais (a arte, a liberdade, o amor), em oposição aos valores materiais (relacionados ao dinheiro), como se observa em vários trechos da canção: ("Vô cantá no cantori primêro / As coisa lá da mĩa mudernage / Qui mi fizero errante e violêro"); ("já curri o mundo intero"); ("O rei me disse fica eu disse não"); ("Si eu tivesse di vivê obrigado / Um dia iantes desse dia eu morro / Deus fez os home e os bicho tudo fôrro"); ("Qui a vida nessa terra é u'a passage"); ("Vai longe cantá o bem da furria").

A oposição entre espírito e matéria é tão explícita, que há a negação asseverada, no refrão, da palavra "dinheiro", que representa tudo o que está relaciondo à matéria ("Amô, furria, viola, nunca dinhêro / Viola, furria, amô, dinhêro não"). Através da negação do dinheiro, que tem poder escravizador, o violeiro assume uma posição sublime, fazendo arte pela própria arte, pelo prazer, aproximando-se, dessa forma, do mundo divinal, representado pelo amor.

Para legitimar seu modo de vida, o violeiro se fundamenta no elemento divino, representado pelas escrituras sagradas, portadoras do principal ensinamento da vida mundana: (“Já vi iscrito no Livro Sagrado / Qui a vida nessa terra é u'a passage / E cada um leva um fardo pesado / É um insinament' qui derna a mudernage / Eu trago bem dent' do coração guardado"). Guerreiro (2007) comenta sobre o caráter "espiritual" do violeiro, que "parece considerar o mundo insignificante, vazio, ilusório e efêmero, em oposição à terra paradisíaca, prometida ao homem para toda eternidade" (GUERREIRO, 2007, p.47). O violeiro, dessa forma, compõe seu ideário, que se baseia na aceitação das condições determinadas por forças divinais, a cada ser vivente ("E cada um leva um fardo pesado"), assim como na abdicação dos bens materiais em prol da liberdade individual.

Através de suas andanças, o enunciador adquire conhecimento do mundo e consegue extrair inspiração para seu fazer artístico até mesmo dos cenários mais críticos ("Mais só dispois de pená pela istrada / Beleza na pobreza é qui vim vê"). O violeiro aprende com a própria vida, "escola" "dualisticamente representada pela livre convivência com a natureza e pelas dificuldades que a sobrevivência no campo lhe impõe" (RAMALHO, 2000, p. 115).

Ao final da canção, há a confirmação dos valores do enunciador ("E sem arrepará se é noite ou dia / Vai longe cantá o bem da furria / Sem um tustão na cuia o cantadô / Canta inté morrê o bem do amô"). O violeiro não se deixa escravizar pelo dinheiro; ele é livre no "mundo vão", assim, pode levar sua arte (a arte pura, espiritual) a todos os lugares e pessoas.

Através da canção, o compositor apresenta um verdadeiro "manifesto" de seu posicionamento: "O Violeiro, se tornou um manifesto da arte de Elomar, em termos de musicalidade, construção poética e inclinação ética" (CUNHA, 2008, p. 18). Dessa maneira, observa-se a paratopia do autor através da constituição de um ethos rústico e, ao mesmo tempo, sensível e resistente. Artista que opta por não aderir às riquezas materiais, que vive apenas da poesia. Através da enunciação, o compositor resiste às imposições do mundo moderno, que, muitas vezes, sobrepõe valores superficiais aos valores profundos, valores da alma.

Outra canção bastante representativa da paratopia do compositor é "Campo branco", que faz alusão à origem da palavra caatinga (do tupi ka'a+tinga), que significa mata branca. A canção apresenta a incorporação do espaço topográfico pelo homem, ambos compartilhando as mesmas características. $\mathrm{O}$ ambiente da caatinga é um 
dos principais embreantes paratópicos na cenografia das canções de Elomar.

$\mathrm{Na}$ cenografia do texto de "Campo branco", o enunciador se dirige diretamente ao ambiente que o circunda. Aqui o espaço - o campo branco - é personificado, assumindo um ethos dolente, equivalente ao ethos do próprio enunciador, como pode ser observado no texto da canção:

Campo branco minhas penas que pena secô / Todo o bem qui nóis tinha era a chuva era o amô / Num tem nada não nóis dois vai penano assim / Campo lindo ai qui tempo ruim / Tu sem chuva e a tristeza em mim / Peço a Deus a meu Deus grande Deus de Abraão / Pra arrancar as pena do meu coração / Dessa terra seca in ança e aflição / Todo bem é de Deus qui vem / Quem tem bem lôva a Deus seu bem / Quem não tem pede a Deus qui vem / Pelas sombra do vale do ri Gavião / Os rebanhos esperam a truvoada chovê / Num tem nada não também no meu coração / Vô ter relampo e trovão / Minh'alma vai florescê / Quando a amada e esperada truvoada chegá / Iantes da quadra as marrã vão tê / Sei qui inda vô vê marrã parí sem querê / Amanhã no amanhecê / Tardã mais sei qui vô tê / Meu dia inda vai nascê / E esse tempo da vinda tá perto de vim / Sete casca aruêra contaram pra mim / Tatarena vai rodá vai botá fulô / Marela de u'a veiz só / Pra ela de u'a veiz só (MELLO, 1978).

Podemos observar, já nos primeiros versos, o ambiente personificado pelo enunciador, na conformação de um ethos compartilhado: o enunciador, um sertanejo acabrunhado, que se refere ao campo em primeira pessoa, em tom de lamento, exprimindo todo o seu pesar. O ethos do enunciador é construído através do uso da variante linguística, que remete ao modo de falar do sertanejo e ao ambiente, com os campos de caatinga, os rios, os pastos etc. Pode-se notar a que a relação dos embreantes sertanejo / campo / chuva, representam, respectivamente, a interação homem / terra / amor. A dor do sertanejo é o reflexo da dor atribuída ao próprio campo, pela ausência do seu amor, a chuva. A opção pelo nome masculino "campo" faz conferir o compartilhamento do ethos sofrido, uma vez que, o campo ressequido, que caracteriza a cenografia da canção, é uma espécie de espelho da própria figura do sertanejo.

Na cenografia, o amor está diretamente relacionado à chuva, o bem maior do campo (terra), logo, o bem maior do sertanejo (homem); o campo, por sua vez, é determinante da tristeza do sertanejo, numa interação cíclica: o homem é reflexo da terra, que é reflexo do homem; a chuva é o amor do campo, logo a chuva é também o amor do sertanejo. Guerreiro (2007), analisando a canção citada, aborda a relação da terra com o poeta: "O penar da terra é decorrente da falta de chuva e o do poeta parece ter duas motivações. A primeira deve-se ao fato da terra estar seca e improdutiva; a segunda deve-se à ausência ou partida de um bem, de um amor" (GUERREIRO, 2007, p. 86). Pode-se, dessa forma, verificar a paratopia do compositor representada pela composição do ethos pesaroso do sertanejo, mas ao mesmo tempo esperançoso com o retorno de seu amor, a chuva. O sertanejo está lastimoso pela partida do seu bem maior, a chuva, mas, ao mesmo tempo, há nele a resistência, ("não tem nada não nós dois vamos penando assim"), e a esperança do retorno daquele bem, que traz a vida (amor) de volta àquela terra aflita, ("minha alma vai florescer"), ("Quando a amada e esperada trovoada chegar").

Desse modo, Elomar transfere para a enunciação sua paratopia ao cantar o amor, e esse amor é também o amor do sertanejo, uma vez que compõe no sertão e sobre o sertão. A paratopia ocorre no investimento cenográfico com a representação da topografia da caatinga, o campo branco e com a constituição do ethos resistente e esperançoso do sertanejo. Um ponto que contribui para a caracterização desse ethos resistente e esperançoso do sertanejo é a fé nas forças divinas: ("Todo bem é de Deus que vem / Quem tem bem louva a Deus seu bem / Quem não tem pede a Deus que vem").

Para complementar a constituição do ethos do sertanejo, há o caráter profético ("E esse tempo da vinda tá perto de vim / Sete casca aruêra contaram pra mim / Tatarena vai rodá vai botá fulo / Marela de u'a veiz só"). A tradição dos "profetas da chuva" é muito comum no Nordeste, nas "previsões" feitas pelos próprios sertanejos sobre se haverá ou não um bom período de chuvas para o ano que está por vir, partindo de observações da natureza e do clima local:

Observando a terra, os bichos, o tempo, trabalhando com o arado, a enxada interagindo com o outro, atuando como um agente receptor das tradições repassadas pela experiência dos mais velhos, acumula-se no trabalhador profeta sertanejo um saber mitológico que resulta ser uma ciência para aquele contexto [...] (MARTINS, 2006, p. 160).

Geralmente, a figura do profeta está associada à do poeta de cordel que profetiza através de versos, coadunando as temáticas da natureza, da ciência e da poesia.

No investimento linguístico a paratopia é observada pelo uso da variedade linguística do sertão nordestino. O uso dessa variedade é um traço destacável nas composições de Elomar, uma vez que é uma das marcas mais fortes do posicionamento do compositor, na busca de exaltar os valores de sua terra que ficaram esquecidos no passado ou corrompidos pela massificação cultural imposta pela mídia. Simões (2006), discorrendo sobre o projeto artístico de Elomar, afirma: 
Elomar, consciente de sua proposta artística, apropriase do material linguístico disponível no Português do Brasil e, ao lado do recolho de amostras de falas de brasileiros representantes dos mais esquecidos rincões, renova a língua [...] a despeito de ações modernizantes comprometedoras de nossa cultura (SIMÕES, 2006, p. 19).

$\mathrm{O}$ código de linguagem do texto da canção "O violeiro" está atrelado à composição do ethos rústico dos habitantes do sertão, uma vez que o universo sertanejo é ativado através da fala dos homens e mulheres que habitam esse espaço e o receptor/ouvinte será levado a identificar, na memória coletiva, a fala do sertanejo. Todavia, é preciso ter em conta que o investimento linguístico também está relacionado à paratopia do compositor, pois o dialeto sertanejo apresentado nos textos das canções é retrabalhado para representar a única forma de linguagem legítima para o posicionamento de resistência à modernidade, defendido por Elomar.

As análises apresentadas são uma amostra de como a obra de Elomar se constitui paratopicamente no campo da música brasileira. Nas canções selecionadas foi possível observar a embreagem paratópica nas cenografias dos textos, com a constituição dos ethé dos enunciadores. $\mathrm{O}$ investimento linguístico contém embreantes que determinam uma paratopia linguística pelo uso de um código de linguagem que reflete o falar do sertanejo. Assim, a composição das cenografias proposta por Elomar nas canções "O violeiro" e "Campo branco" se apresentam tanto na língua quanto na constituição dos ethé, trazendo para o ouvinte o sertão catingueiro, com sua gente e suas vicissitudes, seus amores, suas esperanças, que são, de certa maneira, o retrato da própria condição paratópica do compositor no campo literomusical.

\section{Considerações finais}

O discurso literomusical de Elomar Figueira Mello se constrói numa paratopia que reflete o posicionamento marcado principalmente pela recuperação e valorização da cultura do sertão que, na visão do compositor, encontra-se deteriorada pelo avanço descontrolado da modernidade. A paratopia é a condição paradoxal do compositor no campo literomusical e pode ser observada no modo de gestão de seu processo criativo, de sua interação na instituição discursiva e em suas composições.

Através da observação da embreagem paratópica, no plano verbal das canções analisadas, podemos identificar os elementos que conferem a paratopia do compositor, presentes na configuração de um mundo ético paratópico, através da construção de ethé que representam o sertão catingueiro, idealizado no discurso de Elomar. É o sertão o elemento principal da poética elomariana, que pode ser posta ao lado da poética de Guimarães Rosa e da ideia de "grande sertão", de "Estado do Sertão", isto é, do sertão transcendental.

O mundo ético catingueiro é o principal embreante da paratopia de Elomar, é o lugar de exílio onde compõe sua obra; é um espaço também paratópico, pois se encontra suspenso no tempo e no espaço e que talvez tenha como portal a própria enunciação, pois é através dela que se pode adentrá-lo.

Com as análises das canções "O violeiro" e "Campo branco", podemos verificar como o compositor conduz sua paratopia: tal como os enunciadores das canções, que compõem ethé resistentes, entristecidos, esperançosos, Elomar traz em seu posicionamento o pesar pela perda das referências históricas e culturais do povo sertanejo, ao mesmo tempo em que há a esperança, característica do sertanejo, a esperança de tempos fartos, assim como a "tatarena" citada na canção, prenunciando a chuva. Esperança que seu canto, sua obra, assim como a chuva, ajudem a regar as raízes ressequidas, quase mortas da nossa cultura.

\section{Referências}

BASTOS, Eduardo Cavalcanti. Nova cantoria: movimento poético-musical de Elomar Figueira Mello, Dércio Marques e Xangai. Dissertação (Mestrado em Artes Cênicas) - Programa de Pós-Graduação em Artes Cênicas, Salvador: Universidade Federal da Bahia, Salvador, 2006.

BASTOS, Eduardo Cavalcanti. Cartografias imaginárias no Sertão Medievo de Elomar Figueira Mello. Plural Pluriel revue dês cultures de langue portugaise, 11, 2012. Disponível em: <http://revue1-13.pluralpluriel.org/>. Acesso em: 23 maio 2017.

CHARAUDEAU, Patrick; MAINGUENEAU, Dominique. Dicionário de análise do discurso. 2. ed., $3^{\text {a }}$ reimpressão. São Paulo: Contexto, 2008.

COSTA, Nelson Barros. Música popular, linguagem e sociedade: analisando o discurso literomusical brasileiro. Curitiba: Appris, 2012.

CUNHA, João Paulo. Cantador do rio Gavião. Texto introdutório. In: MELLO, Elomar Figueira. Elomar: Cancioneiro. Belo Horizonte: Duo Editorial, 2008. p. 13-59.

GUERREIRO, Simone. Tramas do sagrado: a poética do sertão de Elomar. Salvador: Vento Leste, 2007.

GUERREIRO, Simone. Trilhas revistas do cancioneiro. In: MELLO, Elomar Figueira. Elomar: Cancioneiro. Belo Horizonte: Duo Editorial, 2008a.

GUERREIRO, Simone. Os múltiplos de um artista antimoderno: Elomar, príncipe da caatinga. In: Anais do XI Congresso nacional da ABRALIC: Tessituras, Interações, Convergências. São Paulo, SP, 2008b. Disponível em: <http://www. abralic.org.br/eventos/cong2008/AnaisOnline/simposios/ pdf/033/SIMONE_GUERREIRO.pdf>. Acesso em: 23 maio 2017. 
MAINGUENEAU, Dominique. Além da paratopia. In: NAVARRO, Pedro (Org.). O discurso nos domínios da linguagem e da história. São Carlos: Editora Claraluz, 2008a. p. 9-20.

MAINGUENEAU, Dominique. Cenas da enunciação. São Paulo: Parábola Editorial, 2008b.

MAINGUENEAU, Dominique. Discurso literário. São Paulo: Contexto, 2006.

MAINGUENEAU, Dominique. Doze conceitos em análise do discurso. São Paulo: Parábola Editorial, 2010.

MAINGUENEAU, Dominique. Ethos, cenografia e incorporação. In: AMOSSY, Ruth (Org.). Imagens de si no discurso: a construção do ethos. 2. ed. São Paulo: Contexto, 2013.

MAINGUENEAU, Dominique. O contexto da obra literária. 2. ed. São Paulo: Martins Fontes, 2001.

MARTINS, José Clerton de Oliveira. O tempo de trabalho na experiência do profeta da chuva. In: MARTINS, Karla Patrícia Holanda (Org.). Profetas da chuva. Fortaleza: Tempo de Imagem, 2006. p. 156-160.

MELLO, Elomar Figueira. Campo Branco [Gravado por Elomar]. In: MELLO, Elomar Figueira. Na quadrada das águas perdidas. Vitória da Conquista: Gravadora e Editora do Rio do Gavião, 1978. 1 CD.

MELLO, Elomar Figueira. Elomar: Cancioneiro. Belo Horizonte: Duo Editorial, 2008.

MELLO, Elomar Figueira. O violeiro [Gravado por Elomar]. In: MELLO, Elomar Figueira. Das barrancas do Rio Gavião. São Paulo: PolyGram, 1972. 1 LP.

RAMALHO, Elba Braga. Cantoria nordestina: música e palavra. São Paulo: Terceira Margem, 2000.

SIMÕES, Darcília (Org.) et al. Língua e estilo de Elomar [versão digital]. Rio de Janeiro: Dialogarts, 2006. Disponível em: <http://www.dialogarts.uerj.br/arquivos/elomar2006_01. pdf>. Acesso em: 23 maio 2017.

Recebido: $31 / 05 / 2018$

Aprovado: 27/07/2018

(D) LIA RAQUEL VIEIRA DE ANDRADE <lia.andrade@unilab.edu.br> Professora, Universidade da Integração Internacional da Lusofonia Afro-Brasileira, Redenção, Ceará, Brasil.

(D) JULIANA GEÓRGIA GONÇALVES ARAÚJO <jgeorgia.araujo@gmail.com> Professora, Universidade Federal de São Carlos, São Carlos, São Paulo, Brasil. 